\title{
Living without left atrium
}

\section{Luis Alvarez-Acosta, ${ }^{1}$ Ana Sanchez-Quintana, ${ }^{2}$ Marcos Farrais-Villalba, ${ }^{1}$ Maria Facenda-Lorenzo ${ }^{1}$}

${ }^{1}$ Department of Cardiology, Hospital Universitario Nuestra Señora de la Candelaria, Santa Cruz de Tenerife, Santa Cruz de Tenerife, Spain ${ }^{2}$ Department of Hematology, Hospital Insular Nuestra Señora de los Reyes, Valverde, Santa Cruz de Tenerife, Spain

\section{Correspondence to}

Luis Alvarez-Acosta,

luisalvaco@gmail.com

\section{DESCRIPTION}

A 51-year-old female patient presented to the emergency room with a 3-month history of increasing dyspnoea, and $5 \mathrm{~kg}$ weight loss. Her medical history was not relevant. Physical examination revealed 100/90 $\mathrm{mm} \mathrm{Hg}$ blood pressure, $98 \mathrm{bpm}$, orthostatic hypotension, a soft grade $2 / 6$ systolic murmur at the left sternal border and bilaterally pulmonary rates. ECG showed normal sinus rhythm with left atrial enlargement. A transthoracic echocardiogram (figure 1A,C,D) revealed a large atrial myxoma ${ }^{1}$ occupying the majority of the left atrium, which prolapsed through the mitral valve during the entire cardiac cycle (videos 1, 3, 4 and 6). Grade II mitral regurgitation, severe mitral stenosis gradient and severe pulmonary hypertension were noted (videos 2 and 5). Left atrial myxoma excision ${ }^{2}$ (figure 1B) and pericardial patch implantation was performed with good recovery and no signs of heart failure to date.
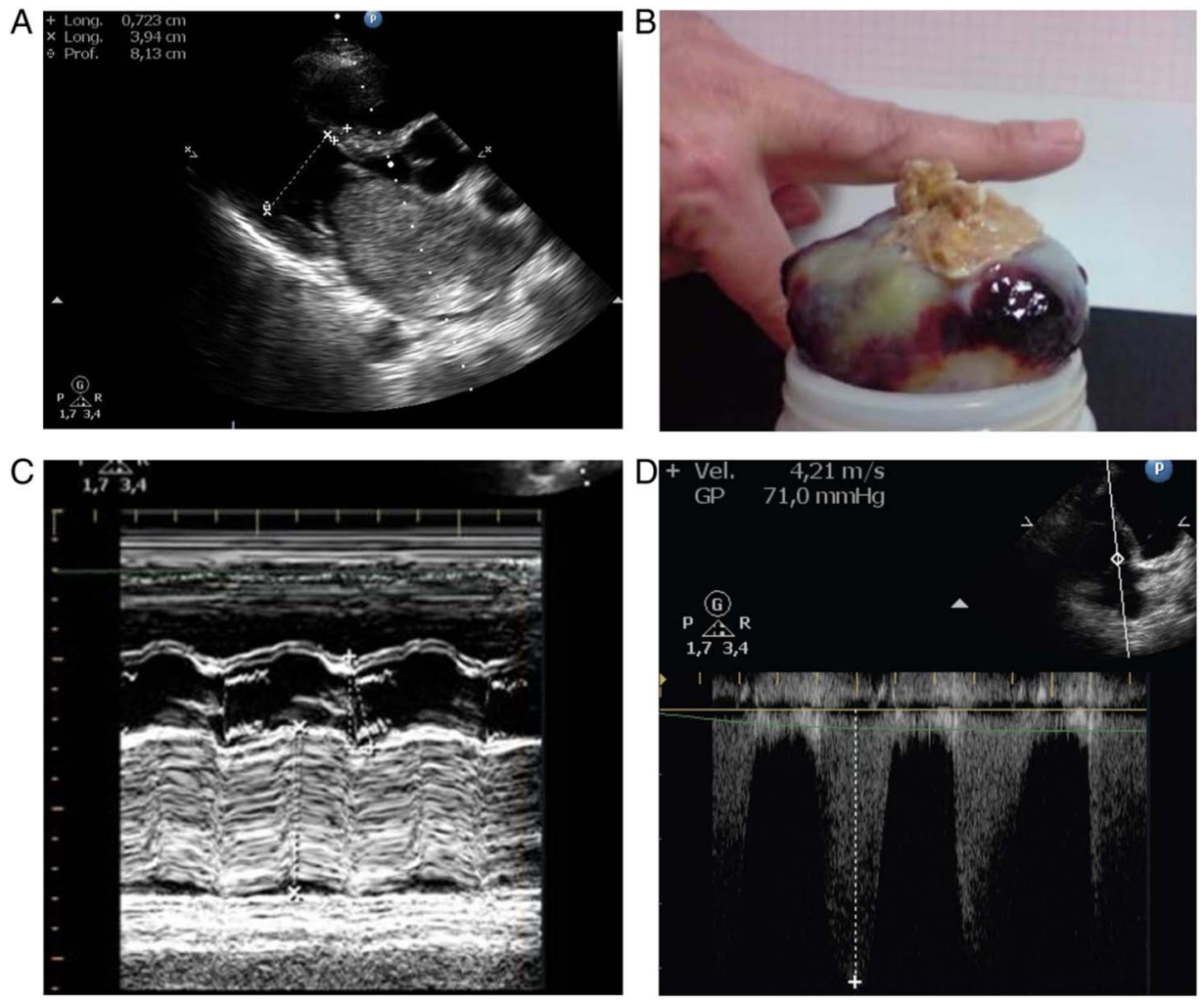

Figure 1 (A) Long axis view. (B) Mixoma with atrial tissue. (C) M-Mode. (D) Transtricuspid gradient. 


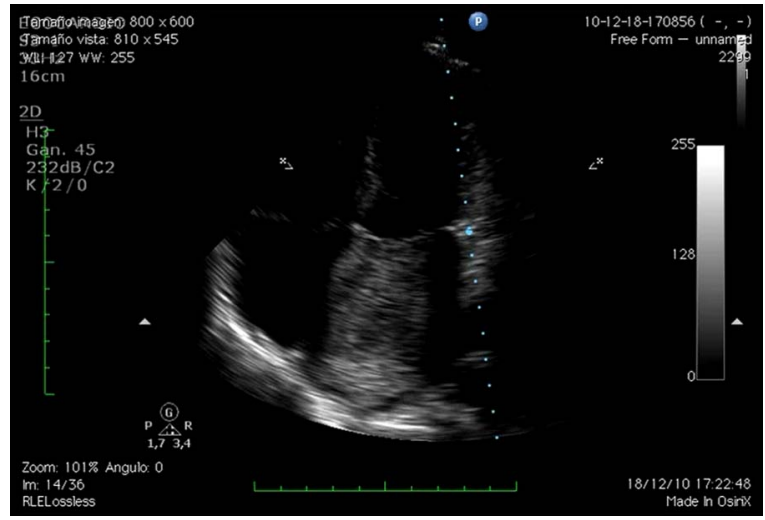

Video 1 Apical 4 chamber View.

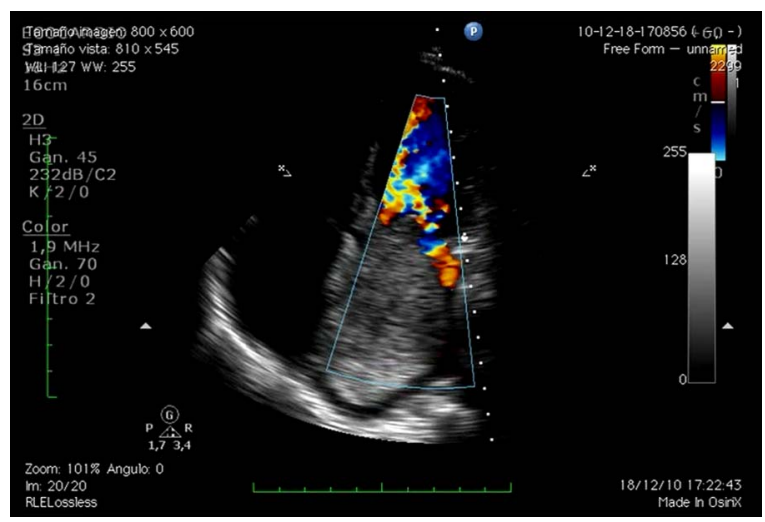

Video 2 Apical Color-Doppler View.

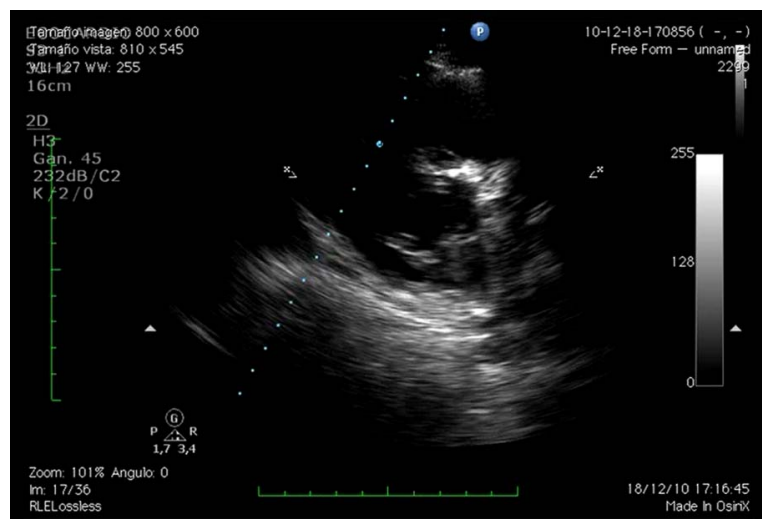

Video 3 Prolapse Through Mitral Valve.

\section{Learning points}

- Slow growing mixomas may take several years to be diagnosed.

- Clinical presentation is normally heart failure, sometimes mimicking mitral stenosis.

Contributors LA-A constructed the hypothesis and contributed to data collection, interpretation, the literature review and the drafting of the manuscript. AS-Q gave expert

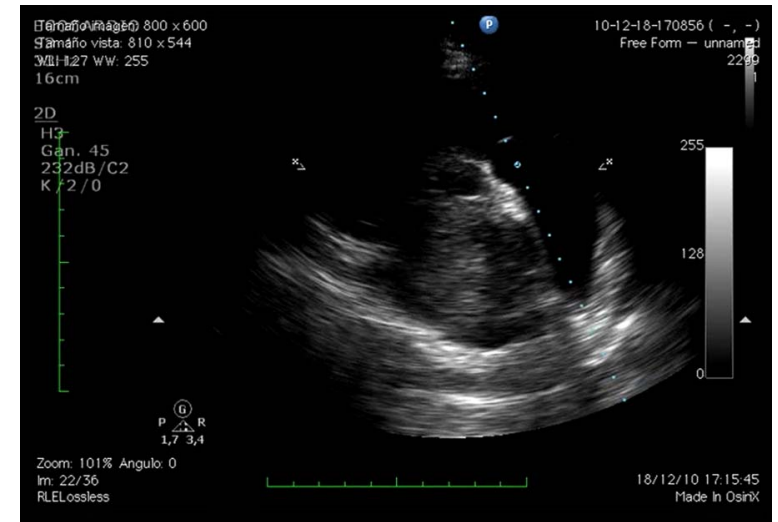

Video 4 Short Axis View Attachment.

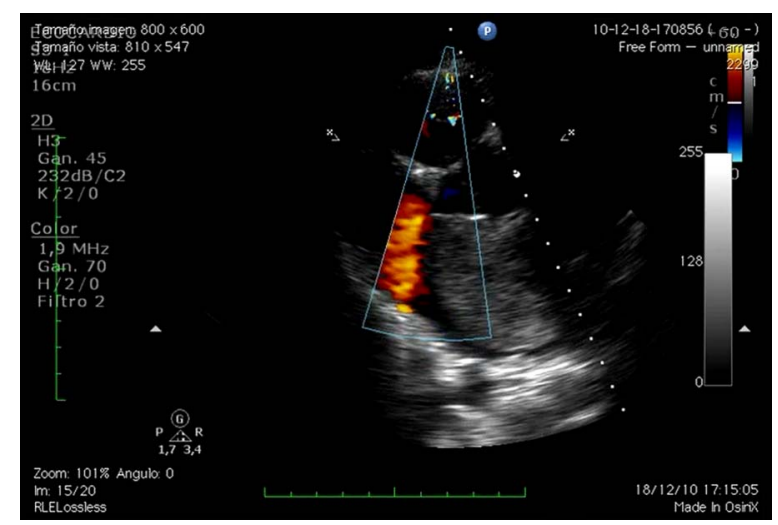

Video 5 Long Axis Color Doppler.

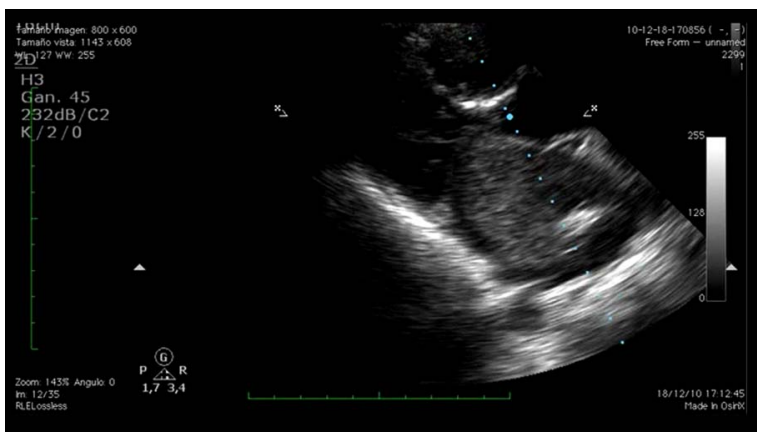

Video 6 Long Axis Movie.

opinion and prepared the images. MF-V helped with the hypothesis and contributed to data collection, interpretation and the literature review. MF-L reviewed the data interpretation, gave expert opinion and reviewed the manuscript.

Competing interests None.

Patient consent Obtained.

Provenance and peer review Not commissioned; externally peer reviewed.

\section{REFERENCES}

1 Lambda G, Frishman WH. Cardiac and pericardial tumors. Cardiol Rev 2012;20:237-52.

2 Yuan SM. Mitral valve myxoma: clinical features, current diagnostic approaches, and surgical management. Cardiol J 2012;19:105-9. 
Copyright 2013 BMJ Publishing Group. All rights reserved. For permission to reuse any of this content visit http://group.bmj.com/group/rights-licensing/permissions.

BMJ Case Report Fellows may re-use this article for personal use and teaching without any further permission.

Become a Fellow of BMJ Case Reports today and you can:

- Submit as many cases as you like

- Enjoy fast sympathetic peer review and rapid publication of accepted articles

- Access all the published articles

- Re-use any of the published material for personal use and teaching without further permission

For information on Institutional Fellowships contact consortiasales@bmjgroup.com

Visit casereports.bmj.com for more articles like this and to become a Fellow 